\title{
Management of Hospital Customer Complaint Using E-Complaint
}

\author{
Ajeng Fitri Setyani,* Bagoes Widjanarko,** Farid Agushybana*** \\ *M Author Correspondence: drajengfitri@gmail.com \\ *Diponegoro University, Semarang City, Central Java, Indonesia \\ **Diponegoro University, Semarang City, Central Java, Indonesia \\ ***Diponegoro University, Semarang City, Central Java, Indonesia
}

\begin{tabular}{l}
\hline I N D E X I N G \\
\hline Keywords: \\
E-Complaint; \\
Complaint Management; \\
HOT FIT Approach;
\end{tabular}

Kata Kunci:

E-Complaint;

Manajemen Komplain;

HOT FIT; \begin{abstract}
A B S T R AC T
Hospital customer complaints must be responded with good complaint management and assisted with e-complaint applications. As a hospital that has applied e-complaint applications for two years, there has never been an evaluation of complaint management using this e-complaint application at the hospital both in terms of the time of complaint completion and quality improvement of hospital services. This study aimed to analyze the implementation of an e-complaint system for managing customer complaint at one of the type-C private hospitals in Central Java using the HOT FIT approach. This study was qualitative research with an exploratory case study design through in-depth interviews using HOT FIT variables, such as Human, Organization, Technology, and Net Benefit. This study involves 8 main informants and 3 triangulation informants. This study showed that organizational aspects play an important role in encouraging people to the successful implementation of technology. Organizational problems can influence time to resolve complaints due to weak monitoring conducted by superiors who can also relate to the use of complaints data as input for quality improvement. Without the support of organizational commitment to run the technology-based system, the benefits of the system will not be obtained to support complaint management. It is recommended for hospitals to optimize organizational functions for the system and encourage staffs so that they achieve the benefits of the system for the organization's performance.
\end{abstract}

\begin{abstract}
Komplain pelanggan rumah sakit harus ditanggapi dengan manajemen penanganan komplain yang baik dan dapat dibantu dengan aplikasi e-complaint. Sebagai rumah sakit yang menerapkan aplikasi e-complaint selama dua tahun, belum pernah dilakukan evaluasi penerapan sistem dalam manajemen penanganan komplain di rumah sakit baik dari segi waktu penyelesaian komplain maupun quality improvement layanan rumah sakit. Penelitian ini bertujuan untuk melakukan analisis penerapan sistem e-complaint dalam manajemen penanganan komplain di salah satu RS swasta kelas C di Jawa Tengah menggunakan pendekatan HOT FIT. Jenis penelitian kualitatif dengan desain studi kasus eksploratorif melalui wawancara mendalam menggunakan variabel HOT FIT yaitu Human, Organization, Technology, dan Net Benefit. Penelitian ini melibatkan 8 informan utama dan 3 informan triangulasi. Penelitian menunjukkan bahwa aspek organisasi berperan penting dalam menggerakkan manusia untuk keberhasilan implementasi teknologi. Permasalahan organisasi dapat mempengaruhi waktu penyelesaian komplain karena lemahnya monitoring yang dilakukan oleh atasan yang dapat berkaitan pula dengan pemanfaatan data informasi komplain sebagai masukan untuk quality improvement. Dengan adanya teknologi yang baik tanpa didukung oleh komitmen organisasi untuk menjalankan sistem maka tidak akan didapatkan kebermanfaatan sistem untuk mendukung manajemen penanganan komplain. Disarankan bagi rumah sakit untuk mengoptimalkan fungsi organisasi terhadap sistem dan menggerakkan staf agar kebermanfaatan sistem/teknologi tercapai sehingga bermanfaat bagi kinerja organisasi.
\end{abstract}

(C) 2019 JMMR. All rights reserved

\section{INTRODUCTION}

Complaints are emotional expressions of customers due to mismatches in the acceptance of the quality of services or products offered ${ }^{-}$and are good momentum as input because they create an opportunity for organizations to identify deficiencies that exist so as to immediately develop recovery strategies to improve quality service. Customer complaints that are not handled properly can adversely affect the level of customer retention, profitability, and organizational image..$^{2}$ According to 
Barlow and Moller, complaints submitted to a company are a gift because customers still want to talk to the company and want the company to make improvements in the future. . $^{-}$

Well-done complaint management will have an impact on increasing customer loyalty. Complaints that are not immediately dealt with quickly will incur huge recovery $\operatorname{costs}^{4}$ and can guide customers to migrate and provide negative information to other potential buyers..$^{2}$ By providing optimal services to complaints, it will increase customer loyalty and can minimize the impact of other losses arising from terrible complaint management. ${ }^{-}$

One private hospital in Central Java has developed an e-complaint system to help complaint management since 2017. E-complaint is a facility for submitting complaints and suggestions online which can be accessed by customers directly or used by hospital officials who receive complaints. The purpose of making an e-complaint application system is to make it easier for the Duty Manager to determine the level of complaints so that it will be easy to assess and determine follow-up complaints. In addition, it is an organizational tool for evaluating complaint management according to the level and as a data center for complaint information in order to make improvements (quality improvement).

E-complaint system can accommodate cross-unit coordination for the resolution of complaints, are able to provide complaint information to the unit or supervisor in real time, document the progress of complaints, as well as provide statistical data on the unit of cause, the most frequent problem/complaint (the frequency), the seriousness of complaint, and the level of complaint using the SAM level (Seriousness Assessment Matrix) which has been modified by setting a target time for the completion of complaints by the hospital.

During two-year implementation, there has never been an evaluation of how the e-complaint system is implemented for complaint management, especially in terms of responsiveness (time of complaint management) and quality improvement (improving service quality) at the hospital. According to Yusof \& Yusuff, an evaluation of an application system is important to assess the effectiveness and success of the application with various evaluation methods, one of which is the HOT FIT model. Evaluation using the HOT FIT approach is not only to see whether a technology is acceptable or applied, but also to look at other characteristics such as human factors and related organizational factors that provide benefits to the organization. This method can be used to evaluate systems in health services that link technology, people, and organizations to produce system benefits. ${ }^{6}$

HOT FIT model is a method for evaluating an application system judged from the aspects of Human, Organizational, Technology, and Net Benefit. The suitability of these three factors can affect the success of a system. This method can be used in evaluating performance, effectiveness, and impact of health information systems on health facilities..$^{-}$The HOT FIT method involves eight dimensions, i.e. System Quality, Quality Information, Service Quality, System Use, User Satisfaction, Structure, Environment, and Net Benefits.

This study aimed to analyze the e-complaint application system in the complaint management at the hospital by looking at the aspects of Human, Organizational, Technology, and Net Benefit to determine responsiveness and quality improvement. From this study, it is expected to find out the benefits of the e-complaint system and constraints that occur in the application, so it can be an input and improve the optimization of the ecomplaint application system.

\section{RESEARCH METHOD}

This study was a qualitative research with exploratory case study design with the aim of analyzing the e-complaint application system in the complaint management using the HOT FIT model approach. Data collection was done through in-depth interview.

In the selection of informants, some criteria were used, such as staffthose who receive complaint, manage complaints, and staff operate the e-complaint system. Meanwhile, the criteria for triangulation informants are policy and policy system determinants, users of e-complaint system data, part of the organization that monitor the evaluation of customer complaint management and the ecomplaint system.

This study used interview guidelines to explore things related to Human which covers system use and user satisfaction; Organization which covers structure and environment, Technology which covers system quality, information quality, and service quality, to produce net benefit (system benefits). The results of indepth interviews were analyzed with thematic content analysis to identify patterns or themes from collected data.

\section{RESULT AND DISCUSSION}

The results of this study are system analysis at the type-C hospital in Central Java. The analysis uses the HOT FIT model approach. 


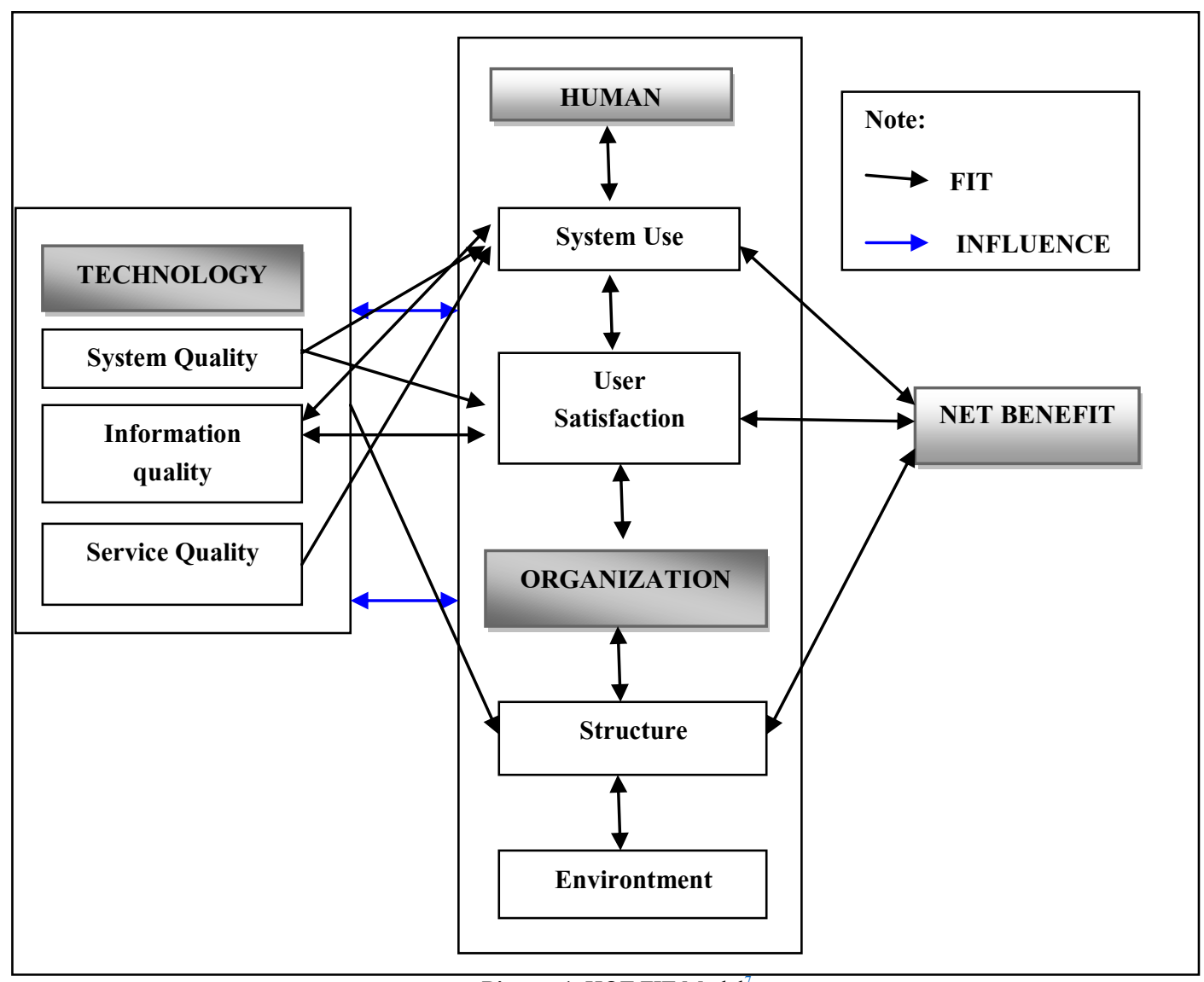

Picture 1. HOT FIT Model-

\section{Human}

In collecting data related to Human viewed from the dimensions of System Use and User Satisfaction, two themes are obtained, including (1) habits and (2) knowledge.

The staff does not depend on the e-complaint system because of the habits that went before the system still exists, such as communicating by phone or via WhatsApp, as seen from the following statement:

"It does not depend, because sometimes Duty Manager did WA to ask for answers because the unit has not had time to input into the system" (U5)

"If used properly, they should depend heavily on this system ............." (T1)

This could have happened because of the staff habits of using the old pattern so that the existing system could not replace the previous method of complaint management as a whole. From this statement, it can also be seen that there is a gap between the staffs and management because of an inadequate understanding about the purpose of the system.
Digital/technology disparity will not occur if there is a shared awareness of the importance of knowledge from the technological aspect. Technology can have a positive or negative impact if someone has a complete understanding about problems in relation to technology.

From the hospital staff's point of view, it is obtained that all staffs have been given outreach and training regarding the operation of e-complaint system, as seen from the following statement:

"The socialization of e-complaint was attended by staffs who operate the system, such as Duty Manager, Shift Coordinator, Head of the room, and Assistant manager" (U1, U2, U6, U8)

"Socialization was conducted before the implementation of e-complaint wich was attended by Duty Manager, Shift Coordinator, Head of the room, and Assistant manager delivered by IT and the Head of the Duty Manager Division." (T1, T2, T3) 
However, because of a two-year implementation period, socialization was only done once before the implementation of the system, as stated below:

"The socialization was done once before IT launched the system" (U5)

"The workshop method was socialized before implementation ..." (T1, T2, T3)

Socialization has a positive and significant effect on increasing work commitment if it is carried out effectively and continuously. Increasing the commitment of employees will make organizational performance better. Knowledge and information obtained from the socialization can be used by employees to be more actively involved in a system. ${ }^{9}$

The informant also knows how and who has the right to access, as seen in the following statement:

"Can be accessed by Duty Manager, Shift Coordinator, Head of the room, and Assistant manager who have privilege" (U3, U4, U7)

"It can be accessed by Shift Coordinator, Head of the room, Duty Managers, and all structural officials according to privilege." (T1, T3)

In the interview, it was found that the main informant knew access rights only to assistant manager level, while the triangulation informant stated that access rights were for all structural officials where were up to the Director level.

There is an information gap between staff and structural officials, where differences in information or knowledge can occur due to inadequate information dissemination.

Effective communication is a very important issue in organizations to foster commitment and shape organizational culture. Not only building the right tools between superiors and subordinates, but also implicitly contributing to organizational performance..$^{10}$

In terms of hospital staff satisfaction with the system, only a few users expressed satisfaction, but all informants stated the system was easy to use.

User satisfaction is subjective, related to perceived benefits and user's attitudes towards a system. User satisfaction must be done by conducting an overall evaluation based on experience of use and the impact of using the system. User satisfaction can be used to measure the success of the system. ${ }^{11}$

User dissatisfaction is related to the achievement of the target time to resolve complaints that are less appropriate so that it causes the system to not be used optimally.

\section{Organization}

In collecting data related to the organizational side (Organization) viewed from the dimensions of Structure and Environment, four themes are obtained, such as (1) authority (2) evaluation (3) communication and (4) facilities.

In e-complaint system, there is an authority regulated by hospital management. The authority differs according to the position level and is regulated in each account, as stated in the statement of the main informants reinforced by the triangulation informant as follows:

"Each official has access to his own account and privileges" (U3)

"Each account has its own privilege according to the position" (U5, U7, U8)

"The authority is carried out by the management, and each level of official has its own account" (T1)

However, a triangulation informant stated that authority was indeed regulated, but the privileged access was not in accordance with what was supposed to be, as seen from the following statement:

"The privilege is determined by each user according to the position level, but in my case the privilege is not in accordance with my position, so I cannot see the progress" (T3)

The above statement can be related to the evaluation of monitoring, in which the staff that has the privilege to monitor and see the progress of the complaint is unable to do so. Aside from the privilege that is not in accordance with the position, some triangulation informants stated that the complaint procedures to the hierarchical level have not proceeded, as stated below:

"If the e-complaint is not answered immediately within two hours, it will rise gradually to the next level. Monitoring is done by e-complaint, but it has not worked well yet" (U2)

"The leader has the role of monitoring and evaluation and help to follow up if complaints are not immediately answered by the unit. Within 2 hours, if the unit does not respond, it goes up to the next level. Unfortunately, it has not worked well yet" (T1) 
Authority arrangements intended to monitor the evaluation of hospital services through a system cannot work well due to problems that are known but not resolved yet. This is because the system has been running for almost two years, but there has been no improvement from the organization.

Constraints related to this system should be handled immediately once staffs know. The person in charge of the system should monitor obstacles and immediately resolve them, so the system can run optimally. By conducting monitoring efforts, problems in the ongoing process can be directly followed up with. $\frac{12}{-}$

The problem of monitoring evaluation also contributes to not unachieved target to solve complaints according to the SAM level target set by the hospital as shown in table 1 below:

Table 1. Respon Time to Handling Complaint

\begin{tabular}{ccc}
\hline Level SAM & Achieved(\%) & Unachieved(\%) \\
\hline 4 & $5 \%$ & $95 \%$ \\
3 & $27 \%$ & $73 \%$ \\
2 & $8 \%$ & $92 \%$ \\
1 & $0 \%$ & $100 \%$ \\
Total & $\mathbf{1 0 \%}$ & $\mathbf{9 0 \%}$ \\
\hline
\end{tabular}

Based on the results of the interview, there are standards for handling complaints, but several informants stated that the existence of the system did not make resolution time better, as stated in the following statement:

"I do not know the comparison, but indeed the target of two hours to trace a complaint is not achieved" (U4)

"With the system, a better standard is not achieved because the trace requires a long coordination" (T3)

The unachieved resolution time in the management of complaints may occur because the unit takes time to answer the complaints trace. Meanwhile, they stated that two hours were too short to answer the complaint.

Time standard is carried out by the division of Duty Manager as the leading system without having discussions with user from the service unit. The timing is done unilaterally based on experience without special studies. This is as stated in the following statement:

"Determined according to the level. At that time, it was determined in the Duty Manager Staff meeting. We think about the resolution of the complaint that we have done in the last three months. There are no special studies." (T1)

In determining policies, it is necessary to study information and fulfill several characteristics which are simple, straightforward, realistic, rational/applicable according to ability, flexible, easily adjusted, and stable..$^{13}$ By determining the time that is considered not possible to be done by staff, making policies cannot be implemented as it should.

According to Kamus Indikator Kinerja Rumah Sakit dan Balai, the responsiveness to complaints goes into one of the hospital's national quality indicators, which is the quality focus on the managerial area. The dictionary states that responsiveness time and follow up on red grading are within maximum of $1 \times 24$ hours, yellow grading within a maximum of 3 days, and green grading within maximum of 7 days. ${ }^{14}$ Meanwhile, the hospital determines level 4 to be responded and completed within a maximum of two hours, level 3 and 2 within a maximum of 2x24 hours, and level 1 within a maximum of $1 \times 24$ hours.

If the hospital wants to apply a better time standard, cross-unit coordination can be done as a communication within the organization by referring to modified standard as set by the hospital. The speed of response to complaints given by hospitals can affect customer satisfaction with the management of complaints made by service providers.

According to the Department of Health and Human Services, one of the important factors for successful complaint management is leadership and organizational commitment. Management plays an important role in creating an environment for managing complaint-handling properly. $\cdot \frac{15}{}$

Monitoring and evaluation is the leader's activity to monitor the course of the organization, assess the achievement of objectives, and see obstacles to the implementation of a program. From monitoring, the data then can be analyzed and interpreted so that it can be input for leaders to make improvements. Through monitoring and evaluation, the success, constraints, and impact of a program can be known.

Without monitoring and evaluation through the ecomplaint system, the purpose of the system which superiors should know complaints in real time will not be achieved. The utilization of e-complaint system is also not optimal because the system is only run by certain units, as stated by the main informants which are reinforced by the triangulation informants as follows: 
"We never put complaints in e-complaints. Our job is just to answer the search only" (U3, U4, U5, U6, U8)

"Every complaint, whether it is from the unit, from DM, from social media (conventional complaints) must be inputted in the e-complaint system, whether it has been resolved directly or not, so it can be documented. Indeed, there is no SOP related to this matter" (T1)

The staffs also did not run the system accordingly because they did not know what to do and the Standard Operating Procedure (SOP) is not available yet. SOP is a document that outlines an activity carried out by someone correctly, consistently, according to the expected standard. ${ }^{16}$

SOP helps an organization to achieve its expected goals. Without SOPs, employees do not know and cannot carry out their duties properly, and the organization cannot conduct monitoring and evaluation because there are no clear standards of evaluation and authority. ${ }^{17}$

Apart from the absence of SOPs, communication gaps between individuals and officials in organizations also contribute to the disuse of the inputs by all units, as stated in the following statement:

"Utilized well to answer a complaint. There was never any confirmation from Duty Manager" (U3, U4, U7, U8)

"I have already discussed this with relevant managers, but indeed there has been no attempt to improvement." (T1)

In organizations, cross-personal and cross-unit communications are required. An organization is a place for people to interact. Organizations look at environment, carry out activities, and make decisions by conducting information processes horizontally and vertically through organizational structure. $\cdot \frac{13}{}$

Effective communication will create good organizational communication and has an impact on organizational progress. ${ }^{10}$ Communication constraints in the organization will have an impact on the continous use of the system where user involvement is very important for the sustainability and the success of each system and its development. $\frac{18}{}$

In addition to internal communication, there are also external communication problems as obtained from interviews related to insufficient direct use of the system as follows:

"Complaints from customers through the system are still small (U1)"
"E-complaints can be accessed by patients directly or they can access from the complaint receiving unit that inputs the complaints. Indeed, the direct use by customers is still very small. (T1)"

The rare direct use of this e-complaint system by customers can be caused by the absence of socialization as obtained from the following statement:

"........... we never informed the e-complaints to patients (U4, U5)"

"We do not socialize the system to customers because the procedure says if there are complaints for a new patient admission. It is still directed to nurses or Duty Manager (T3)"

A new product that the communities use must be socialized or published to public so that people will know and use it. Marketing is a process to communicate and convey values to customers. ${ }^{19}$

In terms of infrastructure, e-complaint system is well-prepared with the adequate infrastructure, such as procurement of servers with large capacity, planting systems in all service unit computers, and creation of user accounts on the cell phone of structural officials.

\section{Technology}

In data collection related to the technology viewed from the dimensions of System Quality, Information Quality, and Service Quality, four themes are obtained, such as (1) quality (2) data information (3) service information and (4) response to the system.

In terms of quality, e-complaint system has a good quality because the system is easy, simple, and accessible to use. Constraints or problems related to the network rarely occur as conveyed by the informants as follows:

"Simple display. It is easy to use. Easy access. Never had trouble" (U3, U5, U6, U7)

"It has a simple appearance. Easily accessible because it is on the unit's computer. The network is never problematic. Yes, it occured once, but the entire internet network was down due to the server errorin tracing the complaint, but it only took a short time to fix (T1)

Besides, the Duty Manager can provide information in form of reports. Other main informants cannot see the information from the system because it is based on their 
own privilege. This is as stated by the informants as follows:

"All information we need is available in the system. The data in each complaint level are clear with which the most frequent unit recieved the complaint and the most frequent complaint are. The Duty Manager is responsible to provide the facilities in reporting complaints "(U2)

"We can only see the search answers that we have given according to our privilege" (U7, U8)

"Information data are given according to privilege. As DM can pull all information data, shift coordinator can only see complaints and answer unfinished searches. If the head of the room and assistant manager see the progress of complaints in each unit, the level manager and the head of division can see complaints and progress throughout the hospital. This data are used as reports" (T1)

"All information data according to the DM division's request have been accommodated in the system according to the privillege. The data are well-documented so that it can be used for complaint reports "(T2)

With good and complete information data according to the privilege/authority, it should benefit the related unit superiors because complaints can be known in real time and data can be used by the unit as further improvement inputs (quality improvement).

Nevertheless, the complaint data obtained from the ecomplaint system have increased on average from 2018 to 2019 as shown in table 2 below:

Table 2. Complaint Average Data

\begin{tabular}{ccc}
\hline Complaint category & $\begin{array}{c}\text { Average in } \\
\mathbf{2 0 1 8}\end{array}$ & $\begin{array}{c}\text { Average in } \\
\mathbf{2 0 1 9}\end{array}$ \\
\hline Administration & 8 & 4 \\
Caring & 6 & 10 \\
Amenities & 11 & 15 \\
Services & 5 & 7 \\
Clinical Procedures & 1 & 2 \\
Total & $\mathbf{3 2}$ & $\mathbf{3 7}$ \\
\hline
\end{tabular}

From the table above, it can be seen that the average complaint per category has increased in terms of caring staffs, facilities, services, and clinical procedures. Meanwhile, the administration category decreased. This is certainly related to quality improvement conducted by the unit.
The increase in complaints in some of these categories shows that there are repeated complaints in the same category. The repetition of the same complaint shows that with the e-complaint system, existing information data have not been used optimally for quality improvement.

Inoptimal use of information data is certainly not caused by technology because technology can provide complete data. These constraints occur due to the lack of commitment of leaders and organizations.

Complaints or customer feedback can be used as a reference for improving service quality. Superior can encourage staffs to imrpove the service quality so that staffs know problems and can participate in the organization.

A leader must become the backbone of the organization and encourage goodorganizational culture that includes mindsets, attitudes, actions, and habits to manage problems and effects around them. Leaders should carry out their roles and functions to influence, direct, and encourage subordinates so that organizational culture runs well..$^{20}$

With the existence of a new system, information related to e-complaint services is very important to be known by the users, such as what can be accommodated by the system, how to operate, what if there are operational constraints, and so forth. Nevertheless, in the manual that has been provided by the hospital, it only contains about how to operate the system. There were no other rules in the form of SOPs, and even some informants said they did not know about the guidelines, as conveyed by the following informants:

"There has already been a guideline in the form of ecomplaint technical guidelines, but indeed it only contains operational methods. There are no other rules" (U1)

"Do not know whether there is a guide or not, as far as I know there is no SOP yet" (U5)

"Do not know if there's a guide or not" (U6, U8)

"There are operational guidelines for e-complaint systems that contain definitions and ways of operating the system" (T1)

Technical instructions and SOPs are necessary in a system. Service providers like IT as programmer and Duty Manager Division as the leading unit have not yet prepared SOP about the system to provide easy use for the users. The provision of guidelines, SOPs, and technical instructions are important to prepare system implementation.

Creating SOP must contain systematic steps, from introducing a product to carrying out technical procedures. ${ }^{17}$ 
The making of this procedure is included in IT governance to ensure that the system can be used properly according to company objectives. System procedures that have been made must be disseminated to all staffs or users to ensure their understanding about the system. This SOP shall be equipped with contact person if there are constraints in the service system. ${ }^{21}$

Constraints on the system rarely occur. If there is a problem, IT staff will respond to obstacles quickly. Quick response from IT staff shows good quality of service to the system. Even so, IT sometimes responds system development and resolution of obstacles in a long time. This is as stated by the informant as follows:

"Rarely comes trouble. If there are network-related problems, IT staff responds quickly" (U3, U5, U6, U7)

"The system error is definitely solved immediately, but the response to development, is longer because there are many IT programs" (T1)

"If there is a problem with the information system, IT staff responds quickly. Obstacles that I experience related to privilege have not been solved; I have complained to my boss and the IT, but there has been no follow up" (T3)

The length of IT response to program development or constraints can occur due to the unavailability of problem solving procedures or related to inadequate IT staffs.

\section{Net Benefit}

E-complaint system has not been considered as a whole benefit by staffs in the service unit. However, the complaint management units regard better complaint documentation as userful sources for reports. The benefits in terms of management are not experienced by the informants. This can be seen from the informant's statement as follows:

"It is useful because it is better in terms of documentation. In terms of complaint management, there are things that have yet to be achieved. For example, time to solve complaints according to the target has not been achieved. So, maybe the benefits of this system are still not optimal" (U1)

"I do not know. Yes, if there are complaints, the task is just to answer. The time standard is also not achieved yet." (U6, U8)
"The benefits are not really experienced by the service unit .. In terms of documentation, it is very useful .......... In terms of complaint management, it may not have been optimal, and the suitable duration to resolve the complaint has not been achieved. "(T1)

"I have not got the benefits of this system as a boss" (T3)

A system can be useful for users, a group, and organization as a whole. The benefit of this system can be seen from work activities and increased productivity in the efficiency of the process, time, and error reduction. ${ }^{11}$

\section{CONCLUSION}

From the research conducted to analyze the implementation of the e-complaint system using the HOT FIT approach, the main problem is the organization can affect the aspects of human and technology to produce net benefit. Organizational problems, such as communication gaps internal and external, as well as weak monitoring by the supervisor can affect the use of the system, the use of complaint information data for quality improvement, and unachived time standard for handling complaints according to the organizational goals. Weak organizational culture and human mobilization can also be a problem in optimizing the system.

Organizational aspects play an important role in moving people to use technology. With good technology but no support from organizational commitment to run the system, there will be no benefit to support complaint management in terms of responsiveness and quality improvement.

It is recommended for hospitals to optimize organizational functions for the system and encourage staffs so that the benefits of the system/technology are achieved for the organization's performance.

\section{REFERENCE}

1. Sangadji EM, Sopiah. Perilaku Konsumen. 1st ed. WK N, editor. Yogyakarta: CV. Andi Offset; 2013.

2. Filip A. Complaint Management: A Customer Satisfaction Learning Process. Procedia - Soc Behav Sci. 2013 Oct 21;93:271-5.

3. Barlow J, Moller C. A Complaint Is a Gift: Recovering Customer Loyalty When Things Go Wrong. 2nd ed. San Fransisco: Berret_Koehler Publisher, Inc.; 2008.

4. Kottler P, Keller KL. Manajemen Pemasaran. 13th ed. Sabran B, editor. Erlangga; 2009.

5. Buttle F. Customer Relationship Management (Manajemen Hubungan Pelanggan) Consepts and Tool. 
Subiyanto A, editor. Bayumedia Publishing; 2004.

6. Yusof MM, Yusuff AYA. Evaluating E-Government System Effectiveness Using an Integrated SocioTechnical and Fit Approach. Inf Technol J. 2013 May 1;12(5):894-906.

7. Yusof MM, Kuljis J, Papazafeiropoulou A, Stergioulas LK. An evaluation framework for Health Information Systems: human, organization and technology-fit factors (HOT-fit). Int J Med Inform. 2008 Jun 1;77(6):386-98.

8. Ahmad A. Perkembangan Teknologi Komunikasi Dan Informasi: Akar Revolusi Dan Berbagai Standarnya. J Dakwah Tabligh. 2012;13(1):137-49.

9. Rumangkit S. Pengaruh Sosialisasi Organisasi Pada Komitmen Afektif Yang Dimediasi oleh Kesesuaian Nilai. J Bisnis Darmajaya. 2016 Nov 18;2(1):34-56.

10. Yildirim O. The Impact of Organizational Communication on Organizational Citizenship Behavior: Research Findings. Procedia - Soc Behav Sci. 2014 Sep 15;150:1095-100.

11. Yusof MM, Paul R., Stergioulas L. Towards a framework for health information systems evaluation. Vol. 5, Proceedings of the 39th Annual Hawaii International Conference. 2006.

12. Elfindri E. Beberapa Teknik Monitoring dan Evaluasi (MONEV). J Kesehat Komunitas. 2011 Nov 16;1(3):106-28.

13. Yunus A. Perencanaan, Implementasi, dan Evaluasi Kebijakan (Fungsi - Fungsi Manajemen). Majalengka: Unit Penerbitan Universitas Majalengka; 2014. 237 p.

14. Kementerian Kesehatan RI Direktorat Jenderal Bina Upaya Kesehatan. Kamus Indikator Kinerja Rumah Sakit dan Balai. Jakarta: Kementerian Kesehatan RI; 2017. 94 p.

15. Department of Health \& Human Services. Guide to Complaint Handling in Health Services. health.vic; 2012. $56 \mathrm{p}$.

16. Tathagati A. Step by Step Membuat SOP. Jakarta: Efata Publishing; 2014.

17. Ajusta AAG, Addin S. Analisis Penerapan Standar Operasional Prosedur (SOP) Di Departemen HRD PT Sumber Maniko Utama. J Mitra Manaj. 2018 May 31;2(3):181-9.

18. Sun Z. User Involvement in System Development Process. In: Proceedings of the 2nd International Conference on Computer Science and Electronics Engineering (ICCSEE 2013). Paris, France: Atlantis Press; 2013

19. Hartono B. Manajemen Pemasaran Untuk Rumah Sakit.
Jakarta: Rineka Cipta; 2010. 281 p.

20. Trioctavia J, Hamid D, Mukzam MD. Peranan Pemimpin Dalam Mengembangkan Budaya Organisasi (Studi Kasus Pada PT. Asuransi Jiwasraya (Persero) Malang Regional Office). J Adm Bisnis. 2016;40(1):150-9.

21. Rahmi A, Susanto TD, Herdiyanti A. Pembuatan Standard Operating Procedure (SOP) Service Desk Berdasarkan Kerangka Kerja Itil V3 dengan Menggunakan Metode Analisis Gap Layanan (Studi Kasus: PT.XYZ, Tangerang). J Tek ITS. 2014;3(2). 